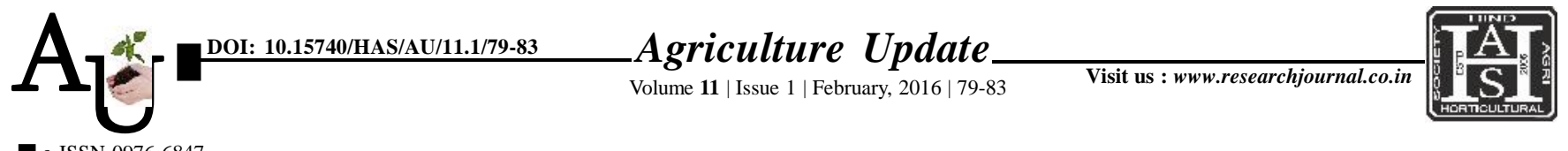

e ISSN-0976-6847

\title{
Research Aвтіcle: Innovative front line demonstrations in Mau district to enhance brinjal income through integrated pest and disease management
}

\section{N.K. SINGH, D.P. SINGH, SAURABH VERMA, N.P. SINGH AND V.K. SINGH}

Article Chronicle: Received : 30.12.2015;

Revised : 15.01.2016; Accepted :

25.01.2016

KEY Words : Brinjal, Frontline demonstration, IPM, Fruit, Shoot borer, Bacterial wilt

Author for correspondence :

\section{N.K. SINGH}

Krishi Vigyan Kendra (N.D.U.A.T.), MAU (U.P.) INDIA

See end of the article for authors' affiliations
SUMMARY : The brinjal crop covers largest area and plays an important role in total vegetable production in India. Brinjal crop suffers more from fruit and shoot borer insect pest and disease attack. Due to lack of awareness of farmers, KVK scientists promoted the integrated pest management practices in district for the suppression of pests and diseases. The integrated pest management strategy involving many components was demonstrated through innovative large scale contagious technology demonstration in 20 ha brinjal (local variety) crop area during the year 2014 during Kharif season in Mau district in Uttar Pradesh, India. The various production and protection parameters indicated that adoption of IPDM strategies decreased the cost of production without affecting the yield. The IPDM demonstration, insecticides sprays quantity reduction in brinjal was 100 lit. per hectare, respectively as compared to the local check. Adoption of IPDM technology increased the net income over the local check in brinjal local varieties Rs. 2,57,500/ha. In spite of increase in yield of brinjal, technological gap, extension gap and technology index existed. The improved technology gave higher gross return, net return with higher benefit cost ratio as farmers' practices.

How to cite this article : Singh, N.K., Singh, D.P., Verma, Saurabh, Singh, N.P. and Singh, V.K. (2016). Innovative front line demonstrations in Mau district to enhance brinjal income through integrated pest and disease management. Agric. Update, 11(1): 79-83. 